\title{
Breach parameters for cascade dams' breaks using physical, empirical and numerical modeling
}

\section{Parâmetros de brecha em rupturas de barragens em cascata utilizando modelagens física, empírica e numérica}

\author{
Rubens Gomes Dias Campos ${ }^{1}$ (D), Aloysio Portugal Maia Saliba ${ }^{1}$ (D), \\ Márcio Benedito Baptista ${ }^{1}$ (D), Victor Hugo Brum Biscaro ${ }^{1}$ (D), Júlia Muniz de Miranda Sá1 (D), Daniel Tuler Passos ${ }^{1}$ (D), \\ Stênio Augusto de Souza Coelho ${ }^{1}$ (D) \& José Antonio Mamani Gómez ${ }^{2}$ (D) \\ ${ }^{1}$ Universidade Federal de Minas Gerais, Belo Horizonte, MG, Brasil \\ ${ }^{2}$ Universidad Nacional del Altiplano Puno, Puno, Perú \\ E-mails: rubensengenheiro2004@yahoo.com.br (RGDC), asaliba@ehr.ufmg.br (APMS), marcio.baptista@ehr.ufmg.br (MBB), \\ victorhugobrumbiscaro@gmail.com(VHBB), juliamdemirandasa@gmail.com (JMMS), danieltpassos@gmail.com (DTP), \\ stenio-augusto@hotmail.com (SASC),jmamani@unap.edu.pe (JAMG)
}

Received: July 27, 2019 - Revised: March 07, 2020 - Accepted: April 15, 2020

\begin{abstract}
The environmental, economic, and social consequences of dam breaks are catastrophic and require their prior knowledge to minimize risks. These consequences are directly related to rupture breach parameters, such as formation time and breach geometry (width, height, and lateral slopes). These parameters must be adequately representative of a real rupture to obtain a rupture hydrograph also representative (temporal evolution, volume, and peak flow). This representation becomes more reliable as the closer to the actual consequences of a rupture it is, thus creating conditions for an adequate emergency action plan. This research evaluates the parameters of breach formation for a possible rupture, specifically for the case of reservoirs in a sequence, also called cascade reservoirs. The adopted methodology uses physical reduced models and numerical modeling to define these parameters, trying to represent two cascade dams, based on a reference case, determining their values in each dam after the simulated rupture events.
\end{abstract}

Keywords: Cascade dam break; Breach equation; breach formation time; physical models.

\section{RESUMO}

As consequências ambientais, econômicas e sociais das rupturas de barragens são catastróficas e demandam seu conhecimento prévio para minimização dos riscos. Essas consequências estão diretamente relacionadas às brechas de ruptura, cujos parâmetros de tempo de formação e geométricos - largura, altura e declividades dos taludes laterais - devem ser adequadamente representativos de uma ruptura real, para que se possa obter um hidrograma de ruptura representativo (evolução temporal, volume e vazão de pico). Esta representação se torna mais fidedigna quanto mais próxima das consequências reais de uma ruptura, criando condições para respostas à emergência mais adequadas. Assim, esta pesquisa determina os parâmetros de formação de brecha para ruptura hipotética, especificamente para o caso de reservatórios em cascata (em série ou em cadeia). Para que possam ser determinados estes parâmetros, a metodologia utiliza modelos físicos reduzidos e modelagem numérica procurando representar duas barragens justapostas em cascata, baseadas em um caso de referência, determinando os parâmetros resultantes em cada barramento após os eventos de ruptura simulados.

Palavras-chave: Ruptura de barragens em cascata; equação de brecha; tempo de formação de brecha; modelos reduzidos. 


\section{INTRODUCTION}

One of the most important aspects to reduce the consequences of a dam break is the prior knowledge of the affected areas and the respective available warning time to civilian population evacuation. This knowledge comes from theoretical rupture studies, technically known as dam break studies, in which the associated hydrographs are obtained and propagated to determine the reached levels, evacuation areas, and the available time.

Rupture hydrographs are a direct function of the volume and type of material stored in dams' reservoirs, as well as the time and manner of their release. In this research, the reservoirs store only water. In a rupture, the embankment undergoes an erosive process, opening a breach and releasing the stored volumes. According to the type of dam, this breach will have different characteristics, and these characteristics will determine the related peak flow and hydrograph shape.

Several authors have developed empirical equations to determine geometric formation parameters for a breach on a single dam break. These equations are a well-known methodology described in the technical literature, such as the empirical equations of Froehlich (2008), von Thun \& Gillette (1990), MacDonald \& Langridge-Monopolis (1984).

However, there are no breach equations developed for cascade dam breaks, assuming that breach development occurs the same way as in a single dam break. Cascade dams' breaks bring a question on how an upstream rupture can affect a downstream dam: should single dam break equations be applied or a change on flow conditions demand a change? This research, based in physical laboratory models and numerical modeling, aims to determine the breach formation parameters for cascade dam breaks, mainly for the downstream dam, based on a reference case.

A broad and extensive literature review found no other study similar to the approach proposed here. As an example, Shi et al. (2015) presented a comparative evaluation between single and cascade (two) dam break scenarios, offering even a mathematical formulation for the breach, but not focusing on the effect of the amount of energy propagated from the upstream dam break that could contribute to a larger breach to be formed on the downstream dam in case of a break.

The research developed by Zhang \& Xu (2017) was done in a transparent laboratory channel $(20.0 \mathrm{~m}$ long, $0.5 \mathrm{~m}$ wide by $1.0 \mathrm{~m}$ high) with physicals models and sought to evaluate a rupture that only occurs on an upstream dam, that will impact on an intermediate dam that could not break, to enable the evaluation of the pressures acting on this intermediate dam. In the case of Zhang \& Xu (2017), it was tried to evaluate, qualitatively and numerically, several possibilities of filling of this intermediate dam reservoir, which allowed to classify two types of possible overtopping patterns.

The studies developed by Bouchehed et al. (2017) used the Telemac 2D program and GIS resources to evaluate flood parameters from cascade ruptures of the Mexa and Bougous dams, both located in Algeria, to estimate the effects of these floods in downstream cities. The authors do not mention which breach equation was used.

Altinakar et al. (2017) have developed a cascade dam break of four dams located in Oak Mountain Park, which in turn is located in the Cahaba Creek Valley. The study included hydrological simulations to obtain hydrographs of a series of ruptures and two-dimensional hydraulics simulations with subsequent georeferencing of flood location. The equations proposed by MacDonald \& Langridge-Monopolis (1984), Froehlich (2008), and von Thun \& Gillette (1990) were used, although they were not developed for this intent.

Luo et al. (2017) tested the Smoothed Particle Hydrodynamics (SPH) method, which is a purely Lagrangian method, to estimate the flows from the cascade break of three dams, comparing the results to physical model experimenting. Nothing is said about breach analysis.

Zhou et al. (2017) used a simulation in a channel with a slope of 12 degrees and 20 meters in length, counting with ten probes along the channel to record the passage of the flows, to verify the effects of the cascade rupture. This research exemplifies the results with a case study of cascade dams in a hydraulic computational model, with Manning coefficient values calibrated for this purpose. The article by Zhou et al. (2017) is not clear about what aspects of the physical model were incorporated into hydrological and hydraulic simulations. However, the differences between a single dam and cascading dam breaks are very significant, as stated in the article.

A series of researchers have developed studies about cascade dam break, but never focusing breach formation and development, as can be cited Li \& Liang (2016), Cao et al. (2014), Huang et al. (2018), Cai et al. (2019).

There were not identified researches or any other material about cascade dam breaks that focus on the main subject, that is, the breach formation due to cascade rupture and the impacts of a shorter formation time and a wider and larger breach in the hydrograph form and peak. This research aims to determine the primary influence of the effects of the cascade dam break, mainly verifying the process of the second breach.

\section{METHODOLOGY}

The phases in the current research are:

- Construction and simulation of cascade dams' physical models concerning the "Preliminary Test" in the laboratory, considering appropriate geometric and erosion rate scales determined by Campos et al. (2018a), as described later;

- Development of a HEC-RAS model to evaluate hydraulic parameters, such as velocities and shear stresses using breach geometry and formation time from preliminary physical model tests. HEC-RAS' results were compared to the results obtained by Campos et al. (2018a), to estimate the cement mass addition into the materials mix used to construct the physical models;

- Construction of cascade dams' models in a laboratory on two dam spacing scenarios;

- Overtopping of the upstream dam from reservoir filling, leading to the downstream dam overtopping. Each dam spacing was tested three times each;

- Registering of the physical models' conditions before (3D scanning of dike geometry) and after testing (3D scanning 


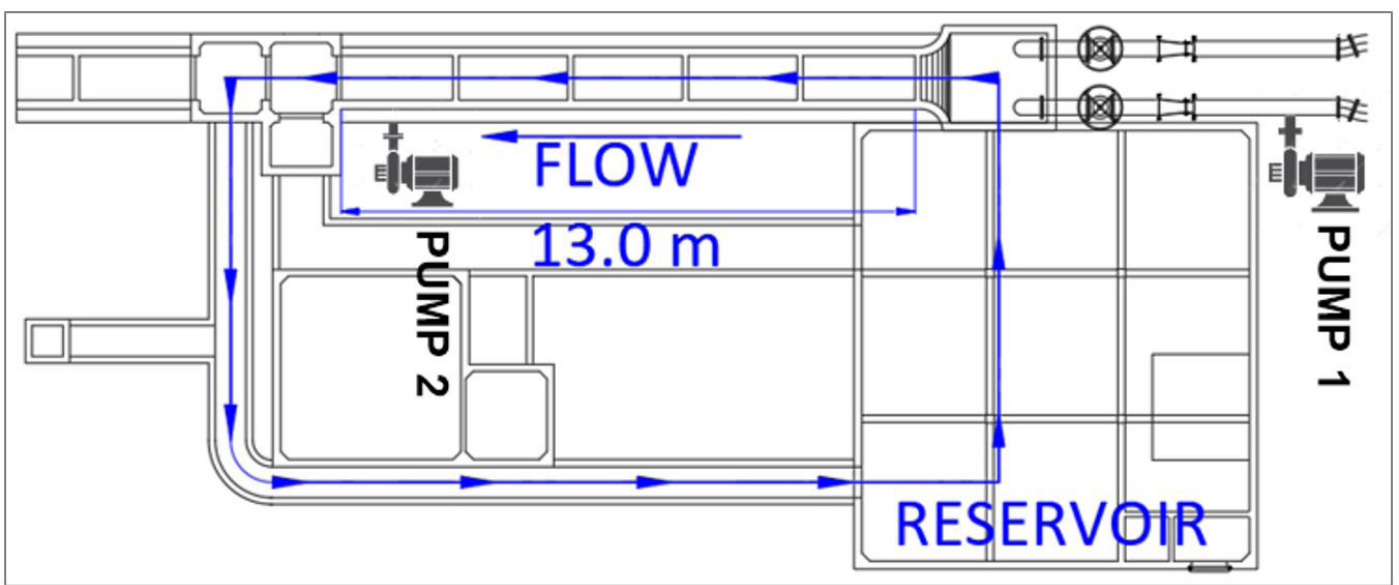

Figure 1. Channel used to simulate cascade physical models' ruptures.

of the dike and breach geometries and breach formation time monitoring);

- Analysis of the physical phenomena involved to obtain representative parameters in cascade dam breaks;

- Comparing models' results to the results from existing empirical breach equations to evaluate their applicability limitations to the cascade dams' break problem;

- Criteria verification of the minimum breach formation time equal to 15 minutes (von Thun \& Gillette, 1990), to check if this is applicable to cascade dams' ruptures;

- A proposition of an equation adjusted to cascade dam break, particularly to the downstream dam.

Due to the impossibility to work with materials such as clayey, silty and sandy soils, as these can damage the pumping system (abrasion, cavitation), turn the water used in the tests useless, due to the coloring these materials add to flow and to undesirable scale effects, it was necessary to replace these soils with inert and insoluble material.

Campos et al. (2018a) evaluated a cohesionless material composed of tire rubber grains, to which small portions of cement were added to provide cohesion on a representative proportion to a real soil, called Rubber Cement Water Mixture (RCWM). Characterization and parameterization of the RCWM have already been fully developed (Campos et al., 2018a), using an adapted apparatus inspired on the equipment described by Briaud et al. (2001), to obtain erosion rates of a RCWM scaled to the real soil erosion rates under the effects of shear stress promoted by a constant flow.

The physical models were simulated at the Hydraulics Research Center (CPH) of the Federal University of Minas Gerais (UFMG), using a prismatic channel shown in Figure 1, which indicates the flow direction and the useful length of this equipment.

The channel used on the tests has a square cross-section with $1.0 \mathrm{~m}$ base per $1.0 \mathrm{~m}$ in height, $13.0 \mathrm{~m}$ of useful length (Figure 1) connecting two boxes, one upstream for entry and regularization of the flow, and another downstream for sediment retention and flow return to reservoir pump.

Due to the dimensions of this channel, the tests' models were settled in an isotropic scale of 1:100, and varying the

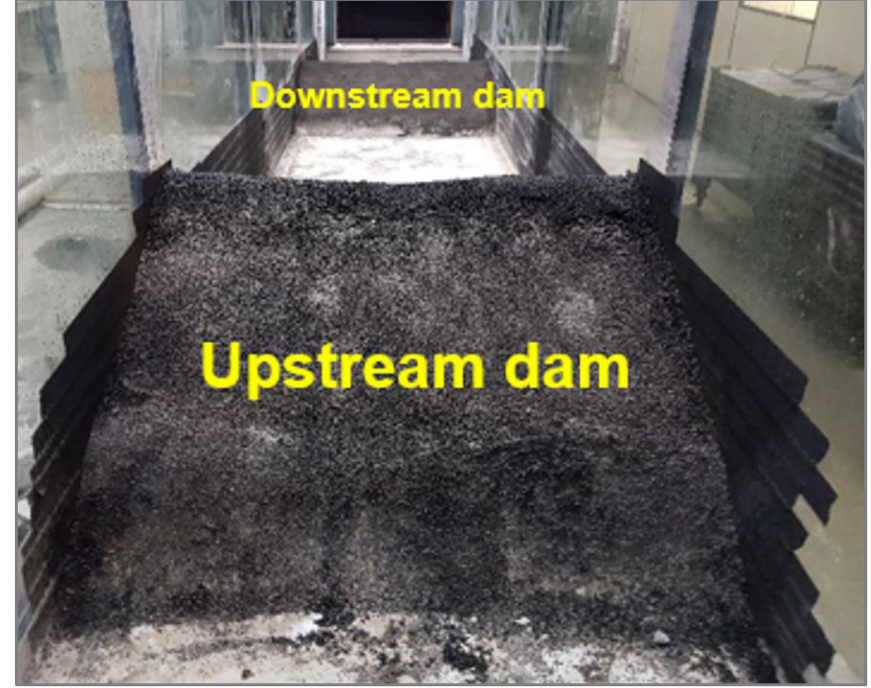

Figure 2. Cascade physical models prepared to test.

distance between the dams to evaluate the effect of routing of the rupture wave.

For mixing and homogenization of the material (RCWM) a concrete mixer of $150 \mathrm{~L}$ of nominal capacity and $70 \mathrm{~L}$ of effective capacity was used.

The channel was previously coated with a black adhesive tape (to allow scanning, as glass transparency and translucent colors cause deformation in the $3 \mathrm{D}$ scanned images), with a rough surface, to fix the models in the correct place and thus to avoid the displacement of the models in relation to the lateral glass channel. Figure 2 exemplifies the conditions of one of the tests elaborated during the research.

The RCWM is a permeable material. It was necessary to waterproof the upstream embankment slope of the dams to avoid dam breaks due to piping. After several attempts, it was successfully developed a technique that uses a fine clayey material, obtained by spraying a $3 \mathrm{~mm}$ layer of powdered clay, then moisturized using a hand-held sprinkler (Figure 2) with no perceptible resistance, but preventing the water infiltration in the dam's embankment and its damaging consequence of forming piping during the test, as this research focuses on the processes of overtopping. 
The equipment used for surveying dams' geometries, in the pre-rupture and post-rupture conditions, was the Kinect II 3D scanning sensor, 3D Scan (Microsoft Corporation). According to Gonzalez-Jorge et al. (2015), the Kinect II 3D scanning sensor has a surface survey accuracy ranging from $0.3 \mathrm{~mm}$ to $7.5 \mathrm{~mm}$ for a range of distance of surveying from $1.0 \mathrm{~m}$ to $4.0 \mathrm{~m}$ (Figure 3 ). Figure 3 shows a comparison between Kinect II and Kinect I 3D scanning sensor, and Kinect II 3D scanning sensor is the most accurate.

The Kinect II, 3D scanning sensor, includes an infrared laser emitter, an infrared camera, and a RGB camera. The depth information is obtained through a triangulation process, and a diffraction grid divides the infrared laser into a specific pattern that is projected into the scene. The pattern is collected by the infrared camera and compared to the projected one. Local offsets generate a disparity map, where larger displacement values correspond to farther positions of the sensor and, conversely, smaller values correspond to places closer to the sensor.

The 3D scanning survey distance on this research is between $1.0 \mathrm{~m}$ and $2.0 \mathrm{~m}$. Measurements' accuracy can vary between $0.3 \mathrm{~mm}$ and $0.4 \mathrm{~mm}$ (Figure 3).

On experiments recording, two Logitech webcams were used, model C920 1080p full HD. MeshLab v2016.12 software was used to obtain and analyze the scanned geometric data of the physical dams' models. Kinovea 8.27 software was used to analyze data from the videos recorded to measure the dam breach width during the Preliminary Tests.

\section{Study development}

The models were developed considering two similarity criteria:

a) The rigid-bed Froude criterion to maintain the same hydraulic conditions;

b) Erodibility criterion, that is, the erosion rate of the RCWM and the real soil must keep similarity.

Erodibility was chosen to be representative instead of other similarity criteria, such as Shields parameter similarity, as compacted soil of earthfill dams shows resistance much greater than alluvial material (Saliba, 2009). The erodibility concept (Briaud et al., 2001) adapts sediment transport concepts to constructed soil structures.

Once these models are located in a prismatic channel, where the lateral flow accelerations can be neglected with respect to the gravitational acceleration, the exact geometric similitude was adopted to characterize the phenomenon of a cascade dam break.

\section{Scale factors}

The flows to be propagated in the models and the prototypes, chosen based on a reference case, are related by the Theory of Similarity using Froude similitude criterion, presented here for the aim of clarity (Equation 1):

$Q_{r}=L_{r}^{2,5}$

Where;

- $\mathrm{Qr}$ is the flow scale factor (dimensionless);

- $\mathrm{Lr}$ is the geometric scale factor (dimensionless).

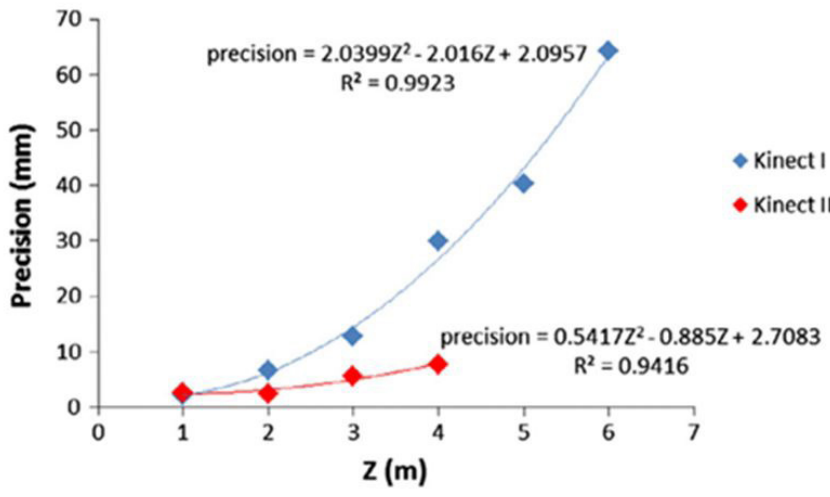

Figure 3. Precision range trend for Kinect I and Kinect II (Gonzalez-Jorge et al., 2015).

Table 1. Range of flows simulated on the physical model.

\begin{tabular}{cc}
\hline $\begin{array}{c}\text { Range of hydrological flow } \\
\left(\mathbf{m}^{3} / \mathbf{s}\right)\end{array}$ & $\begin{array}{c}\text { Flow on the physical model } \\
-\mathbf{Q r}\left(\mathbf{m}^{3} / \mathbf{s}\right)\end{array}$ \\
\hline 2,500 & 0.025 \\
1,500 & 0.015 \\
\hline
\end{tabular}

Preliminary simulations were carried out in a hydrological program with the hydrological data of the upstream and downstream dams, based on the reference case, to determine the range of extreme possible flows during a rupture event, which should be simulated in the dams' physical models (Table 1).

The scales of width $(W)$, height $(b)$ and length $(x)$ are related to the geometric scale $\left(L_{r}\right)$ through Equations 2 to 4:

$h_{r}=L_{r}$

$W_{r}=L_{r}$

$x_{r}=L_{r}$

In these equations, subscript $r$ indicates the ratio between variables of the prototype and of the model.

In the case of the variable time $(t)$, the scale between models and prototypes is defined by Equation 5, from the kinematic criteria:

$t_{r}=\sqrt{L_{r}}$

$U_{r}=\sqrt{L_{r}}$

Equation 5 is applicable to the model's breaching formation time to the prototype. It is important to mention that erodibility is essentially an erosion velocity $(U)$, and its scale can be found after applying Equation 6.

The rubber material used to construct the dams had its granulometry defined with retained percentage as $54.7 \%$ (\#1.70 mm), 27.7\% (\# $1.18 \mathrm{~mm}$ ), 12.1\% (\# $850 \mu \mathrm{m}$ ), 4.2\% (\# $500 \mu \mathrm{m}$ ), 0.8\% (\# $355 \mu \mathrm{m}$ ), 0.1\% (\# $250 \mu \mathrm{m}$ ), 0.3\% (\# $45 \mu \mathrm{m}$ ). Considering the scale equations presented, this material could have a real size between $4.5 \mathrm{~mm}$ and $170.0 \mathrm{~mm}$ and could be classified as a mixture of sand, gravel and cobble, present in many dams. The rubber material had a specific weight of $1.30 \mathrm{~g} / \mathrm{cm}^{3}$. 


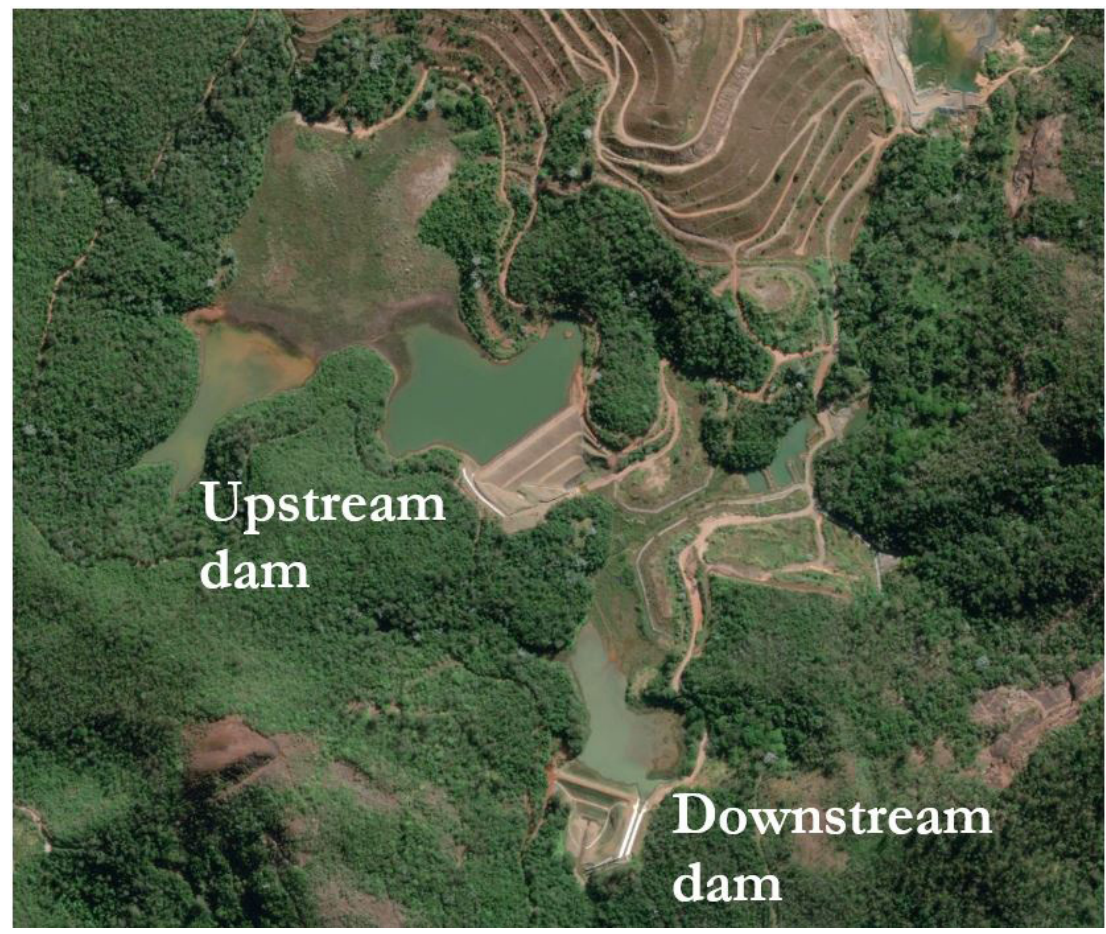

Figure 4. Reference dams in a panoramic view. (Source: Google Earth, 2019).

\section{Reference case}

The dams on which this research was based are located in Minas Gerais. These structures were identified through Google Earth. Figure 4 shows the arrangement of the dams that inspired this research.

Table 2 presents the main data to characterize the upstream and the downstream dams.

Froehlich (2008) proposed equations to determine breach parameters from dam height and reservoir volume, as stated by Equations 7 and 8:

$\bar{B}=0.27 k_{o} V_{W}^{0.32} H^{0.04}$

Where $\bar{B}$ is the average width of a breach (m), ko is shape factor (1.3 on overtopping or 1.0 on piping failure modes), $V_{W}$ is reservoir storage at the time of failure $\left(\mathrm{m}^{3}\right), H$ is the height of the dam $(\mathrm{m})$, and:

$t_{f}=63.2 \sqrt{\frac{V_{w}}{g H^{2}}}$

Where $t_{f}$ is breach formation time (hours), and $g$ is gravity $\left(9.81 \mathrm{~m} / \mathrm{s}^{2}\right)$.

Table 3 presents the breach characteristics obtained by applying data from Table 2 on Equations 7 an 8.

On Table 3, the Storage Intensity (SI) is defined as follow (Colorado Dam Safety Branch, 2010):

$S I=\frac{V_{w}}{H_{w}}$

Where $\mathrm{H}_{\mathrm{w}}$ is the maximum water height inside the reservoir (m) and other terms were previously defined.

Also, according to MacDonald \& Langridge-Monopolis (1984), Breach Formation Factor (BFF) is estimated by Equation 10:

$B F F=V w \cdot H w$
Table 2. Presents the reference dams' characteristics.

\begin{tabular}{|c|c|c|}
\hline Variable & $\begin{array}{c}\text { Upstream } \\
\text { dam }\end{array}$ & $\begin{array}{c}\text { Downstream } \\
\text { dam }\end{array}$ \\
\hline Crest elevation $(\mathrm{m})^{1}$ & 688.00 & 660.70 \\
\hline Invert elevation (m) ${ }^{1}$ & 657.00 & 637.20 \\
\hline Dam height $(m)^{2}$ & 31.00 & 23.50 \\
\hline Dam width $(m)^{1}$ & 201.0 & 134.0 \\
\hline Dam length $(m)^{1}$ & 135.0 & 81.0 \\
\hline Reservoir volume $\left(\mathrm{m}^{3}\right)^{2}$ & 800,200 & 400,000 \\
\hline
\end{tabular}

${ }^{1}$ Estimated based on Google Earth (2019); ${ }^{2}$ Brazilian Mining Dam's Ranking from the Brazilian Mining Agency (ANM) - January/2019 (Agência Nacional de Mineração, 2019).

Table 3. Reference dams' characteristics.

\begin{tabular}{lcc}
\hline \multicolumn{1}{c}{ Variable } & $\begin{array}{c}\text { Upstream } \\
\text { dam }\end{array}$ & $\begin{array}{c}\text { Downstream } \\
\text { dam }\end{array}$ \\
\hline Breach Formation Factor $\left(1000 \mathrm{~m}^{3} . \mathrm{m}\right)$ & 24,806 & 9,400 \\
Storage Intensity $\left(\mathrm{m}^{3} / \mathrm{m}\right)$ & 25,813 & 17,021 \\
Breach formation time $^{1}$ (min.) & 9.7 & 9.1 \\
Crest breach width $^{1}(\mathrm{~m})$ & 62.2 & 48.2 \\
Average breach width $^{1}(\mathrm{~m})$ & 31.2 & 24.7 \\
Invert breach width $^{1}(\mathrm{~m})$ & 0.2 & 1.2 \\
Breach height $^{1}(\mathrm{~m})$ & 31.00 & 23.50 \\
ko coefficient $^{1}$ & 1.3 & 1.3 \\
Breach lateral slope $^{1}(\mathrm{~V} / \mathrm{H}):$ & 1.0 & 1.0 \\
\hline 'Cal & &
\end{tabular}

${ }^{1}$ Calculated according to Froehlich (2008).

\section{Models' concept}

This research aims to determine the variables with the greatest influence on the downstream dam breach. Conceptually, it is quite clear that the distance between the dams and the hydrograph of rupture are key factors. Considering the conditions of the existing 
test channel at $\mathrm{CPH}$ and the reference case as an inspirational source, Preliminary Test (Table 4 ) and test scenarios were defined (Table 5). The variables $h_{2}, h_{2}, h_{1}$ ' and $h_{1}$ " refer to the heights of two ballasts (Figure 5) that represent the natural terrain, on which the physicals models of the upstream and downstream dams were installed. Additionally, to data in Tables 4 and 5, the cement ratio adopted in the RCWM used to build the dikes was $5.0 \%$ by mass in Preliminary Test and $4.5 \%$ by mass in scenarios tests.

The variables Dams heights $(H)$ were set to $19.0 \mathrm{~cm}$, base lengths were set to $81.0 \mathrm{~cm}$, and dam widths were approximately $1.0 \mathrm{~m}$ (the channel width) for both dams to turn the tests more comprehensive. The distance between dams in Scenario II is in an exact scale of the prototype, and the distance between dams in Scenario I is reduced.

The scheme of Figure 5 represents the upstream and downstream dams to illustrate how the geometric variables changed. These two ballasts (Figure 5) had the same slope of the reference case's terrain, evaluated at $0.0374 \mathrm{~m} / \mathrm{m}$. Both were constructed with RCWM, but with a much higher cement ratio by mass than that used in the dam models. This ratio was set to $15.0 \%$ by mass, to avoid base erosion from extreme hydraulic conditions during embankment dam breaks.

Pump 1 was used to fill the upstream reservoir, while Pump 2 filled the downstream reservoir (Figure 5). The flow rate set up for Pump 1 was $0.016 \mathrm{~m}^{3} / \mathrm{s}$ using a frequency inverter. An auxiliary curve relating frequency to flow was used covering the range of scaled flows (Qr), from $0.015 \mathrm{~m}^{3} / \mathrm{s}$ to $0.025 \mathrm{~m}^{3} / \mathrm{s}$ (Table 1). Since Pump 2 has a fixed flow value of $0.003 \mathrm{~m}^{3} / \mathrm{s}$, it was easier operationally to control the volumes of reservoirs with a minimum flow on Pump 1, which still keeps it in the range of $Q r$. It is important to reinforce that both reservoirs should be filled at the same time, to make the testing representative. Furthermore, the main variables for the breach size are volume and height of the dam (Equation 7).

\section{RESULTS}

The development and parameterization of RCWM can be found in Campos et al. (2018a), while some other pre-test results can be found in Campos et al. (2018b).

Preliminarily to the simulations with the scenarios I and II, an unsteady flow regime one-dimensional model was developed using HEC-RAS, version 5.0.7, to evaluate the cascading breach conditions of velocities and shear stress in the channel with Preliminary Test data (Table 4), to determine exactly which cement ratio by mass in RCWM to use.
This HEC-RAS model represents the channel shown in Figures 1 and 2, and it has 1,243 cross-sections, one at every centimeter. The dams are represented as Inline Structures, with the upstream boundary condition of flow hydrograph and downstream boundary condition set as normal depth.

This numerical model simulated a hydrograph varying between $0.001 \mathrm{~m}^{3} / \mathrm{s}$ and $0.125 \mathrm{~m}^{3} / \mathrm{s}$. This maximum flow was calculated by a uniform flow equation based on breach width of the Preliminary Test, obtained using Kinovea software to analyze the recorded dam breach formation movie.

Flow velocities and respective shear stresses were calculated by HEC-RAS form Manning equation and energy line slope, considering gradually varied flow conditions.

Upstream and downstream breaches simulated showed a time of formation of $65 \mathrm{~s}$ and $33 \mathrm{~s}$, breach width of $628 \mathrm{~mm}$ and $1000 \mathrm{~mm}$, respectively, and vertical sidewalls for the two dams. Figures 6 and 7 depict the HEC-RAS model in a longitudinal profile and a 3D perspective view, respectively. Figure 6 demonstrates the dimensions, and Figure 7 reflects the arrangement of the cross-sections of the HEC-RAS model.

Velocity and shear stress were calculated along with the HEC-RAS model, from upstream to downstream (channel distance 13.0 to 0.0 ). The results of the Preliminary Test incorporated in the HEC-RAS model are shown in Figure 8.

Table 4. Preliminary Test I (IP) scenarios of a cascade dam break.

\begin{tabular}{cccccc}
\hline Scenario & $\begin{array}{c}\text { Distance } \\
\text { between } \\
\text { dams } \\
(\mathbf{c m})\end{array}$ & $\begin{array}{c}\text { h2' } \\
(\mathbf{c m})\end{array}$ & $\begin{array}{c}\text { h2” } \\
\mathbf{( c m})\end{array}$ & $\begin{array}{c}\text { h1' } \\
\mathbf{( c m})\end{array}$ & $\begin{array}{c}\text { h1” } \\
(\mathbf{c m})\end{array}$ \\
\hline IP & 203.8 & 2.0 & 5.0 & 12.0 & 17.0 \\
\hline
\end{tabular}

Table 5. Testing scenarios of cascade dam breaks.

\begin{tabular}{ccccccc}
\hline Scenario & Test $\begin{array}{c}\text { Distance } \\
\text { between } \\
\text { dams } \\
(\mathbf{c m})\end{array}$ & $\begin{array}{c}\text { h2' } \\
(\mathbf{c m})\end{array}$ & $\begin{array}{c}\text { h2” } \\
(\mathbf{c m})\end{array}$ & $\begin{array}{c}\text { h1' } \\
(\mathbf{c m})\end{array}$ & $\begin{array}{c}\text { h1” } \\
(\mathbf{c m})\end{array}$ \\
\hline I & 1 & 203.8 & 2.0 & 5.0 & 12.0 & 17.0 \\
& 2 & & & & & \\
II & 3 & & & & & \\
& 1 & 465.0 & & & 27.0 & 30.0 \\
& 2 & & & & & \\
\hline
\end{tabular}

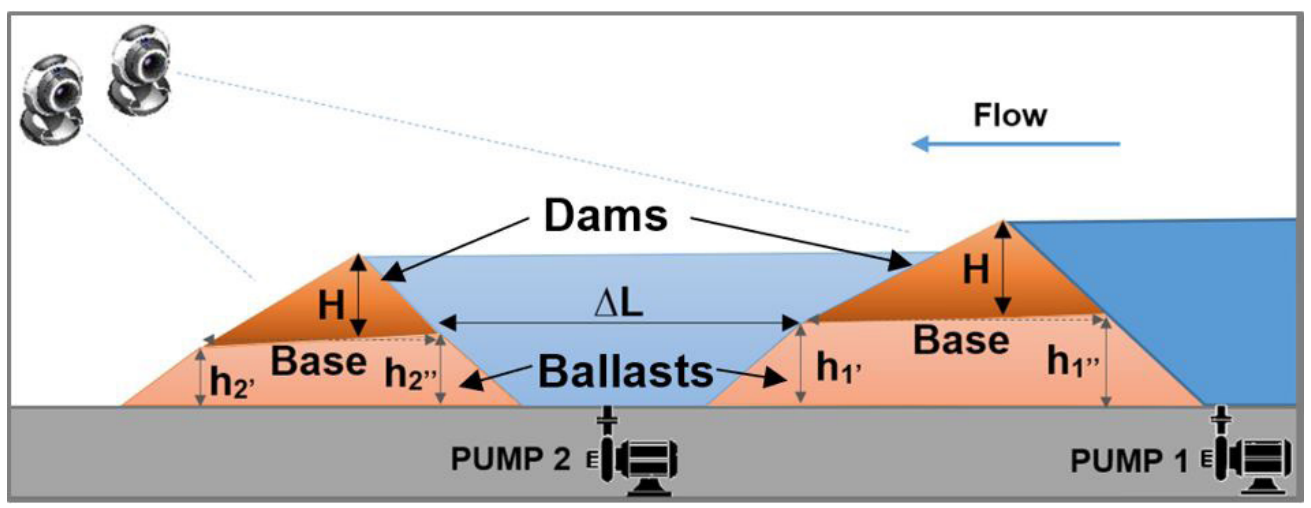

Figure 5. Model variables and Pumps 1 and 2 schematics location. 
Figure 8 shows flow velocities varying from $0.29 \mathrm{~m} / \mathrm{s}$ to $0.72 \mathrm{~m} / \mathrm{s}$ and indicated amplitude for flow shear stress ranging from $0.92 \mathrm{~N} / \mathrm{m}^{2}$ to $6.25 \mathrm{~N} / \mathrm{m}^{2}$, next to the dams. Under these hydraulic conditions, according to Campos et al. (2018a), the cement ratio by mass in RCWM that leads to a constant vertical loss rate of embankment material for testing should be between $2.3 \%$ and $7.8 \%$.

Flow shear stresses have not an exact correlation between the range determined in the numerical model and those determined for the Erosion Apparatus of the RCWM (Campos et al., 2018a). It is important to notice that the shear stress calculation method applied for the RCWM resistance test is valid for closed pipes and that the equation used in HEC-RAS 5.0.7 is valid for open channels (U. S. Army Corps of Engineers, 2016, Campos et al., 2018a). Besides flow pressures were below $10 \mathrm{kPa}$ on RCWM tests, compatible with field overtopping conditions, an open channel erosion testing apparatus in suggested for future works or an adaption to calculate flow shear stresses.

Thus, a $4.5 \%$ cement ratio by mass was adopted to build the dams with RCWM, as indicated by the velocities range from the numerical model. The use of higher cement ratios in the RCWM, as suggested by the shear stress analysis, may lead to indestructible physical models by the action of the flow or to extremely long rupture times, or both. Cement rate is a crucial testing parameter as it would make it impossible to analyze the cascade rupture process, turning it into a non-representative test.

As an example, Figures 9 to 17 present the analysis of the remarkable moments of the breach formation process in the upstream dam of Scenario I, Test 3, indicating the exact time of erosive rupture events and a brief description of qualitative dynamics of a dam break. Figures 18 to 23 present the analysis of the remarkable moments of the breach formation process for the downstream dam of Scenario I, Test 3.

The 3D scanned pictures found in Figures 24 to 27 are the geometry of physical models of upstream and downstream dams at the pre and post conditions of rupture, Scenario I, Test 3, shown here as an example.

A cross-section taken close to the crest of the physical model of the dams was analyzed to represent the breach widths using the MeshLab V 2016.12 software to manipulate scanned surfaces.

The values of the laterals slopes geometries $(\mathrm{h} / \mathrm{v})$ for the upstream and downstream dams are listed in Table 6 . The results of the three tests for Scenarios I and II are listed in Table 7, the breaches' width digitally measured in the 3D scanned dams (1 $\mathrm{mm}$ precision), time of formation, determined by analyses of records. The summation of the occupied area determined the reservoirs' volumes.

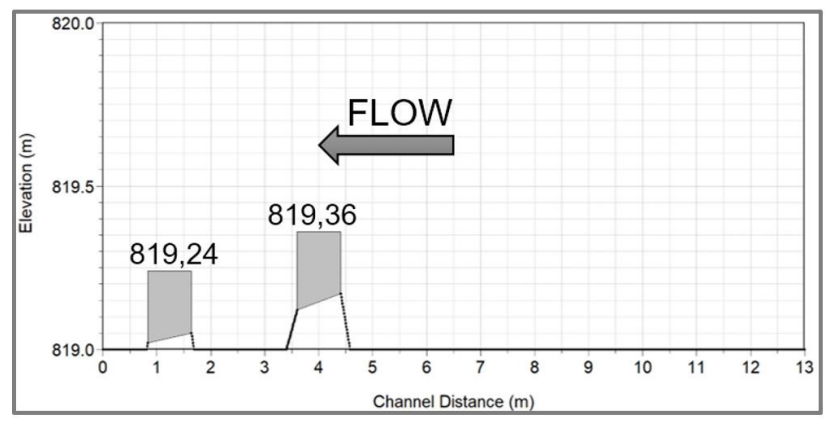

Figure 6. HEC-RAS model channel profile for the Preliminary Test conditions.

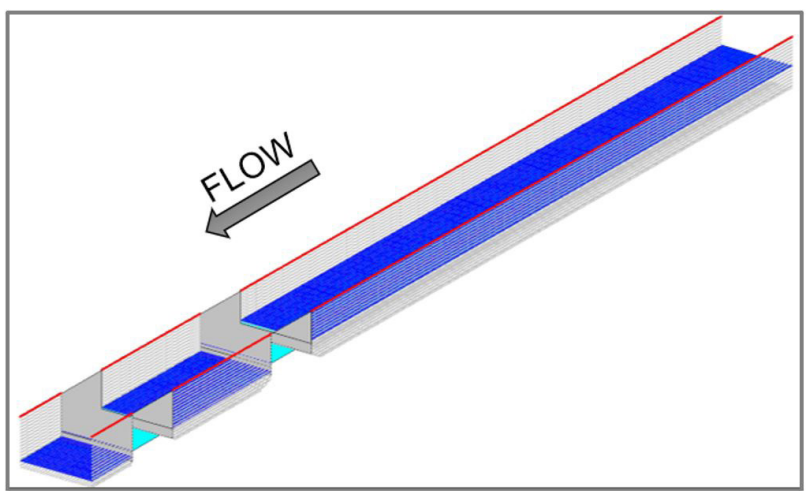

Figure 7. HEC-RAS model channel perspective view for the Preliminary Test conditions.

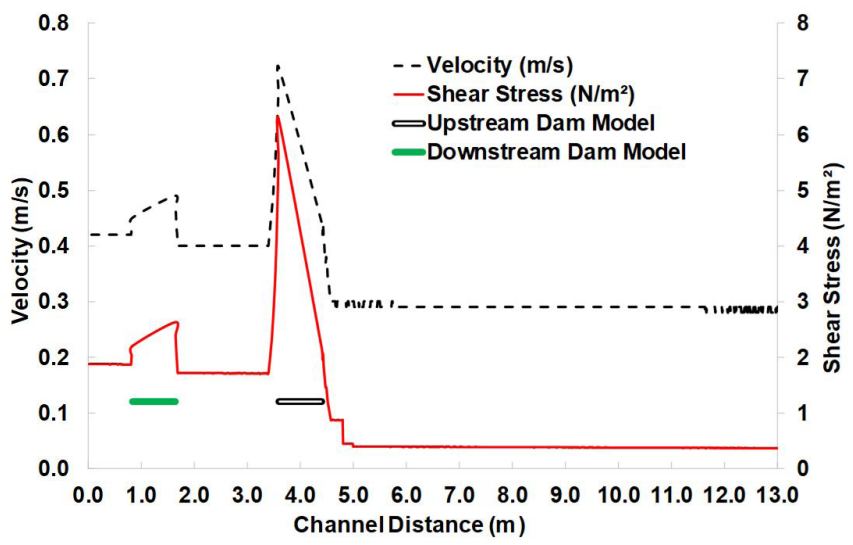

Figure 8. Scenario IP HEC-RAS model results.

Table 6. Scenario I (Tests 1, 2 and 3) and Scenario II (Tests 1, 2 and 3) lateral slopes results.

\begin{tabular}{|c|c|c|c|c|c|c|c|}
\hline \multirow{3}{*}{ Scenario } & \multirow{3}{*}{ Test } & \multicolumn{2}{|c|}{ Upstream dam } & \multirow{3}{*}{ Scenario } & \multirow{3}{*}{ Test } & \multicolumn{2}{|c|}{ Upstream dam } \\
\hline & & Right bank & Left bank & & & Right bank & Left bank \\
\hline & & $(h / v)$ & $(\mathrm{h} / \mathrm{v})$ & & & $(h / v)$ & $(\mathrm{h} / \mathrm{v})$ \\
\hline \multirow[t]{3}{*}{ I } & 1 & -0.02 & -0.07 & I & 1 & 0.44 & 0.41 \\
\hline & 2 & 0.02 & 0.12 & & 2 & 0.00 & 1.06 \\
\hline & 3 & 0.00 & 0.12 & & 3 & 0.00 & 0.00 \\
\hline \multicolumn{2}{|c|}{ Average } & 0.00 & 0.05 & \multicolumn{2}{|c|}{ Average } & 0.15 & 0.49 \\
\hline Scenario & Test & $(\mathrm{h} / \mathrm{v})$ & $(\mathrm{h} / \mathrm{v})$ & Scenario & Test & $(\mathrm{h} / \mathrm{v})$ & $(\mathrm{h} / \mathrm{v})$ \\
\hline \multirow[t]{3}{*}{ II } & 1 & 0.08 & 0.15 & II & 1 & 0.00 & 0.00 \\
\hline & 2 & 1.76 & 1.45 & & 2 & 0.00 & 0.00 \\
\hline & 3 & -0.05 & 0.43 & & 3 & 0.00 & 0.00 \\
\hline \multicolumn{2}{|c|}{ Average } & 0.60 & 0.68 & \multicolumn{2}{|c|}{ Average } & 0.00 & 0.00 \\
\hline \multicolumn{2}{|c|}{ General average } & 0.30 & 0.37 & \multicolumn{2}{|c|}{ General average } & 0.07 & 0.25 \\
\hline \multicolumn{3}{|c|}{ Upstream general average } & 0.33 & \multicolumn{3}{|c|}{ Downstream general average } & 0.16 \\
\hline
\end{tabular}


Table 8 lists the BFF parameter for the upstream and downstream reservoirs, and the following correlations as defined:

- Relationship between downstream and upstream dam reservoir volumes;

- Correlation between downstream and upstream physical models breach widths;
- Correlation between downstream and upstream physical models breach formation times.

Table 8 shows a general average of the correlations (downstream and upstream) of breach widths and breach formation times. Overall results' analyses indicate that the breach formation time is substantially lower for the downstream dam and that the downstream breach is wider and higher.

Table 7. Scenario I (Tests 1, 2 and 3) and Scenario II (Tests 1, 2 and 3) results.

\begin{tabular}{|c|c|c|c|c|c|c|c|}
\hline Scenario & Test & $\begin{array}{c}\text { Upstream } \\
\text { breach width } \\
(\mathrm{mm})\end{array}$ & $\begin{array}{c}\text { Downstream } \\
\text { breach width } \\
(\mathrm{mm})\end{array}$ & $\begin{array}{c}\text { Upstream } \\
\text { time } \\
\text { formation (s) }\end{array}$ & $\begin{array}{l}\text { Downstream } \\
\text { time } \\
\text { formation (s) }\end{array}$ & $\begin{array}{c}\text { Upstream } \\
\text { reservoir } \\
\text { volume }\left(\mathrm{m}^{3}\right)\end{array}$ & $\begin{array}{c}\text { Downstream } \\
\text { reservoir } \\
\text { volume }\left(\mathrm{m}^{3}\right)\end{array}$ \\
\hline \multirow[t]{3}{*}{ I } & 1 & 601.3 & 803.8 & 49 & 16 & 2.653 & 0.352 \\
\hline & 2 & 627.3 & 857.1 & 31 & 19 & & \\
\hline & 3 & 794.8 & 1000.0 & 26 & 20 & & \\
\hline \multicolumn{2}{|c|}{ Average } & 674.5 & 887.0 & 35 & 18 & - & - \\
\hline \multirow[t]{3}{*}{ II } & 1 & 630.4 & 1000.0 & 16 & 13 & 2.106 & 0.813 \\
\hline & 2 & 768.2 & 1000.0 & 7 & 6 & & \\
\hline & 3 & 640.0 & 1000.0 & 20 & 16 & & \\
\hline \multicolumn{2}{|c|}{ Average } & 679.5 & 1000.0 & 14 & 12 & - & - \\
\hline \multicolumn{2}{|c|}{ General average } & 677.0 & 943.5 & 24.8 & 15.0 & - & - \\
\hline
\end{tabular}

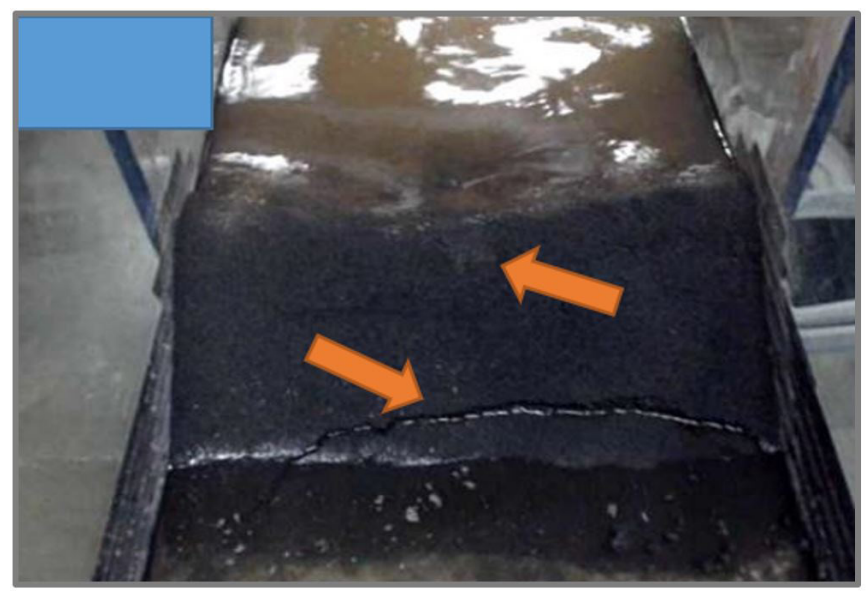

Figure 9. Start of displacement in the low part of the downstream slope simultaneously to the overtopping - time 3':30'.

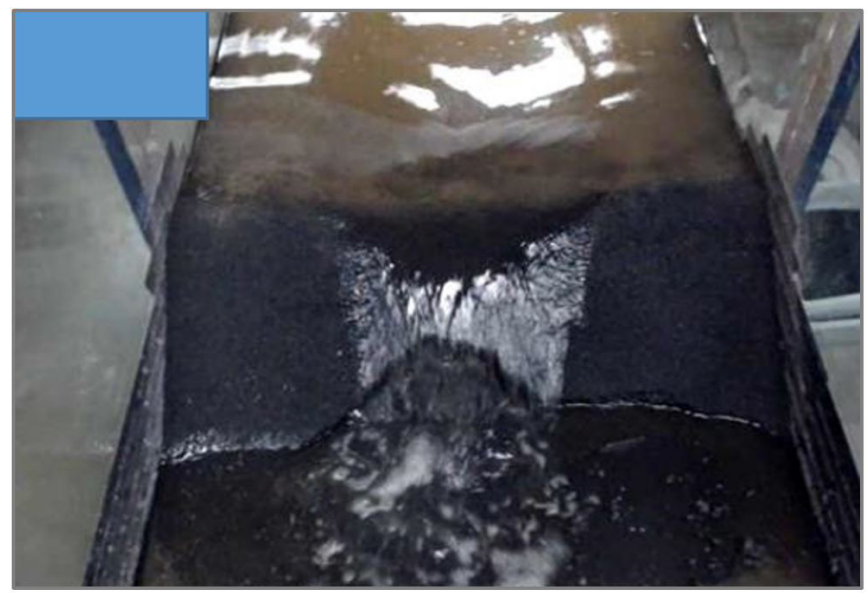

Figure 10. Flow coming from the reservoir promotes the beginning of the removal of material on the lower part of the downstream slope - time 3':34".

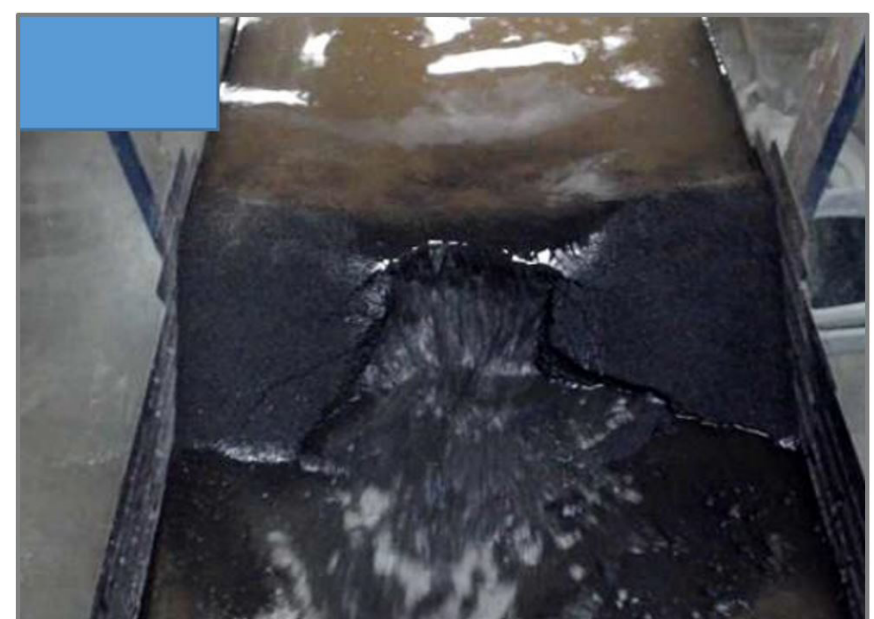

Figure 11. Breach develops upward and widens - time 3':36’.

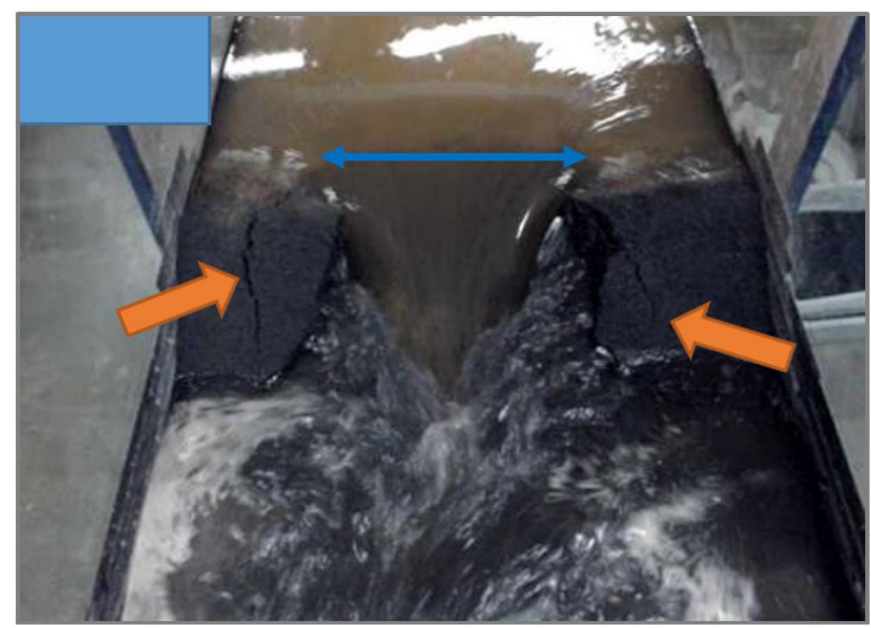

Figure 12. Breach widens fast due to the removal of large portions of material - time 3':43'". 


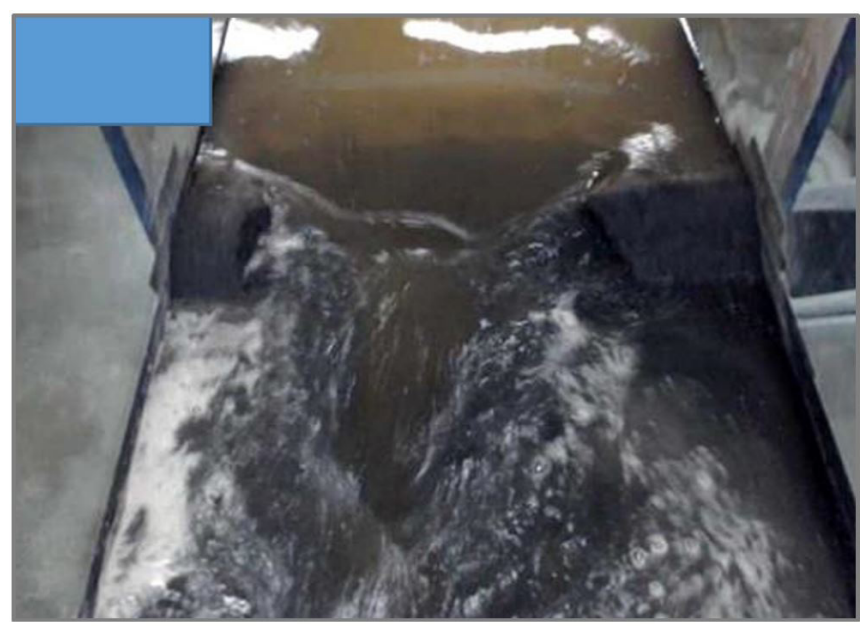

Figure 13. The downstream reservoir is full, and backwater fills the breach area - time 3':46".

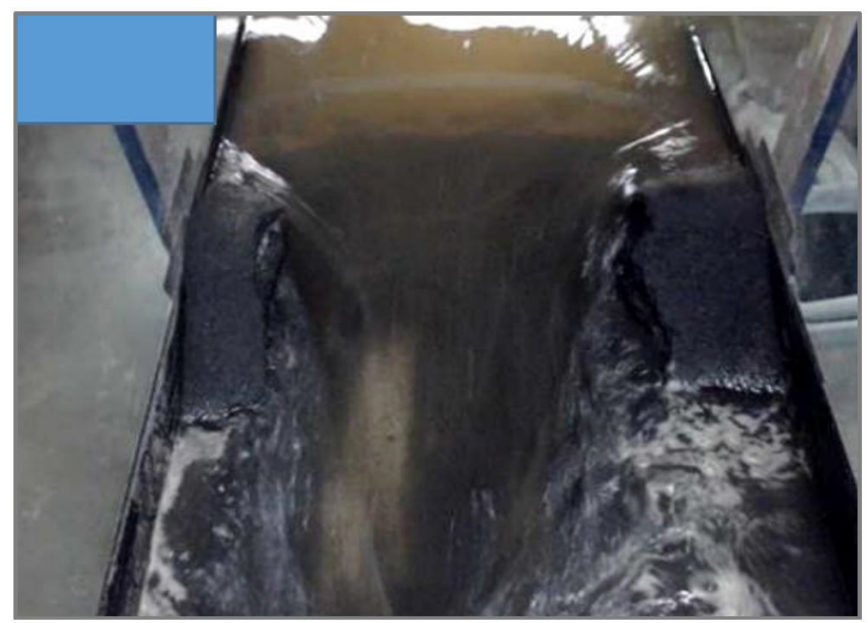

Figure 14. After the downstream dam-break, the reservoirs quickly empty, increasing the breach upstream - time 3':53'”.

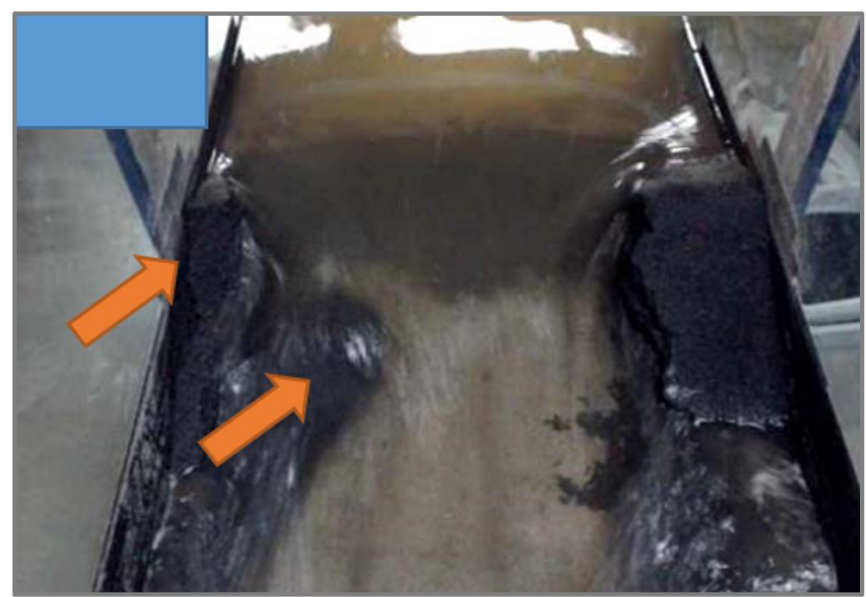

Figure 15. Detachment of parts of left crest and progressive removal of material from the slopes - time 3':56".

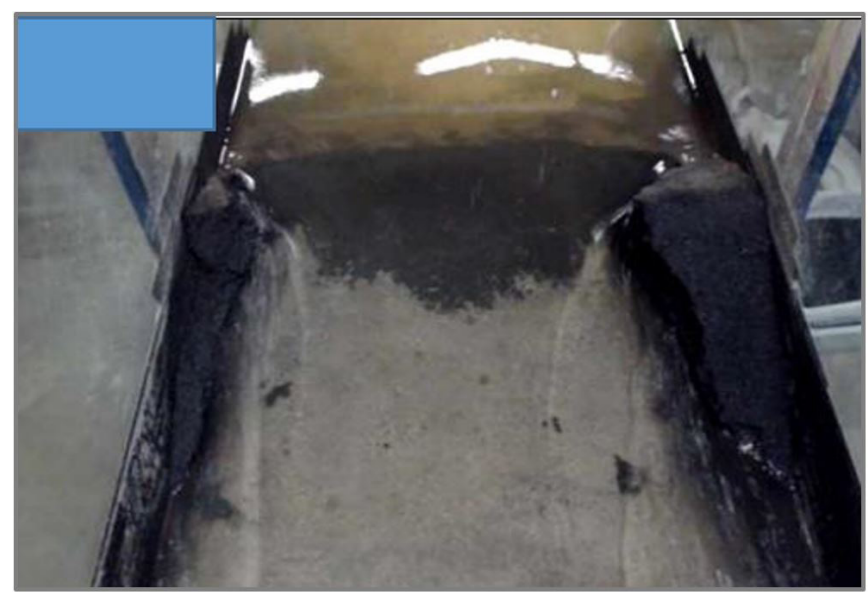

Figure 16. With flow flatting, the formation of grooves in the lower part of the slopes occurs, but the breach practically does not develop anymore. - time 4':02".

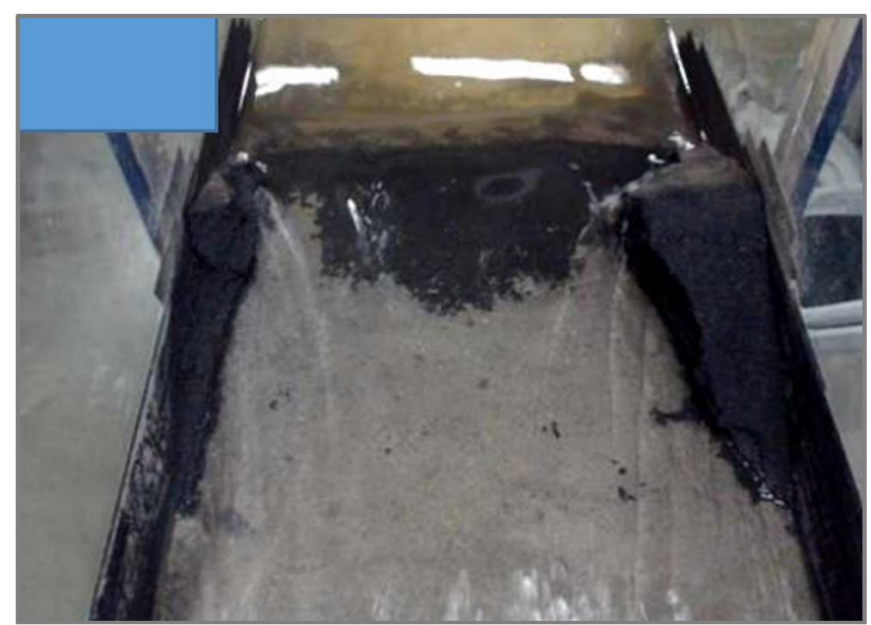

Figure 17. End of test on the upstream dam - time 4':16".

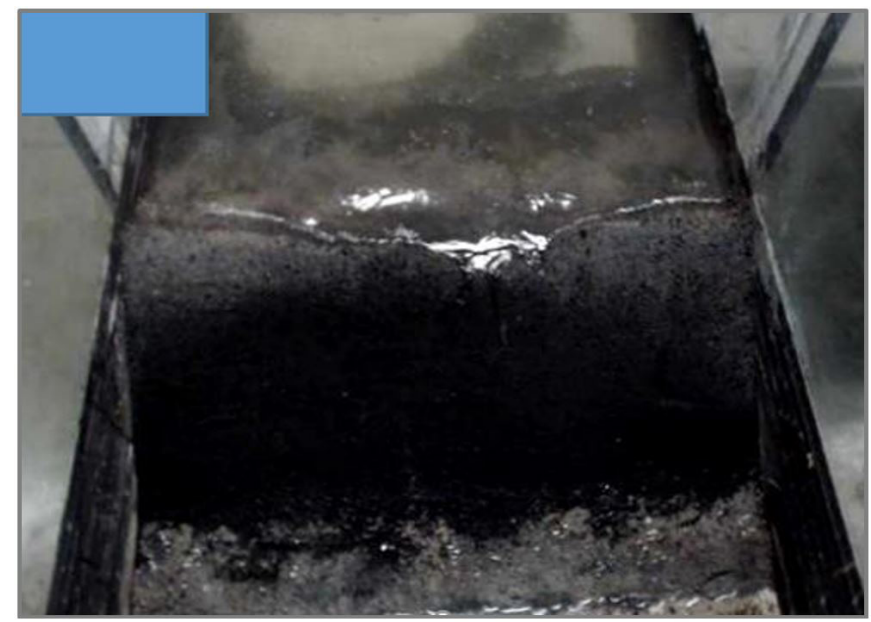

Figure 18. Beginning of the overtopping, with the arrival of the upstream rupture wave - time 3':38'. 


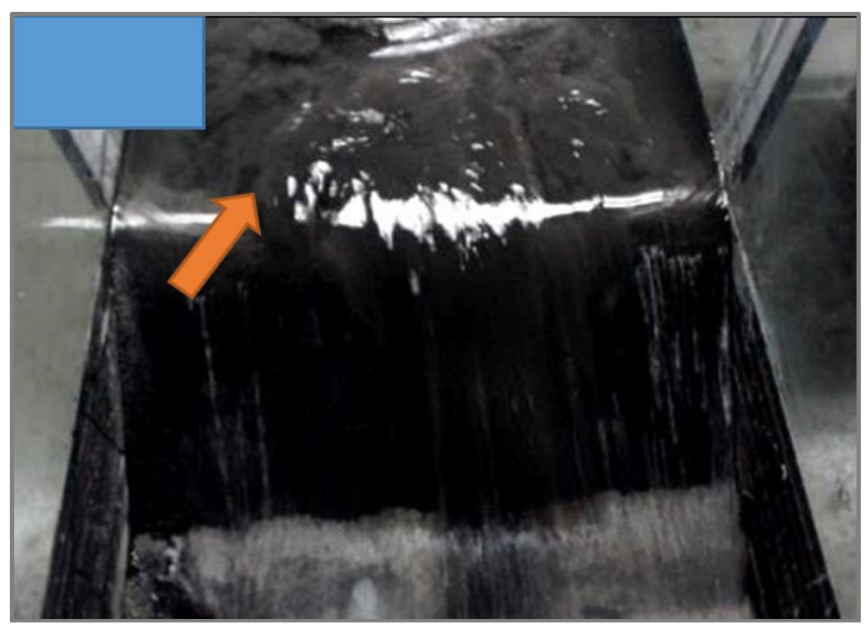

Figure 19. The arrival of material removed from the upstream dam. - time 3':41".

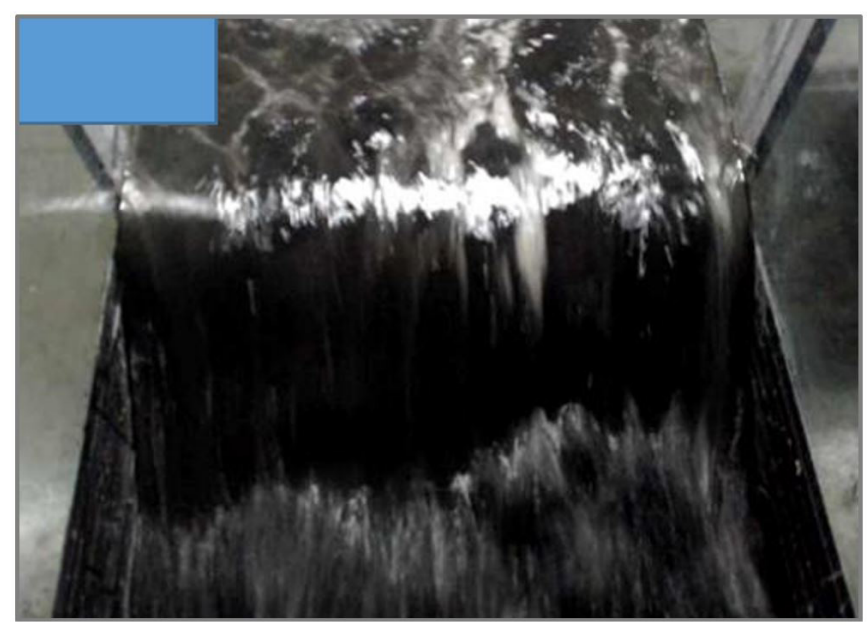

Figure 20. Overtopping occurs throughout all the crest of the downstream dam - time 3':44".

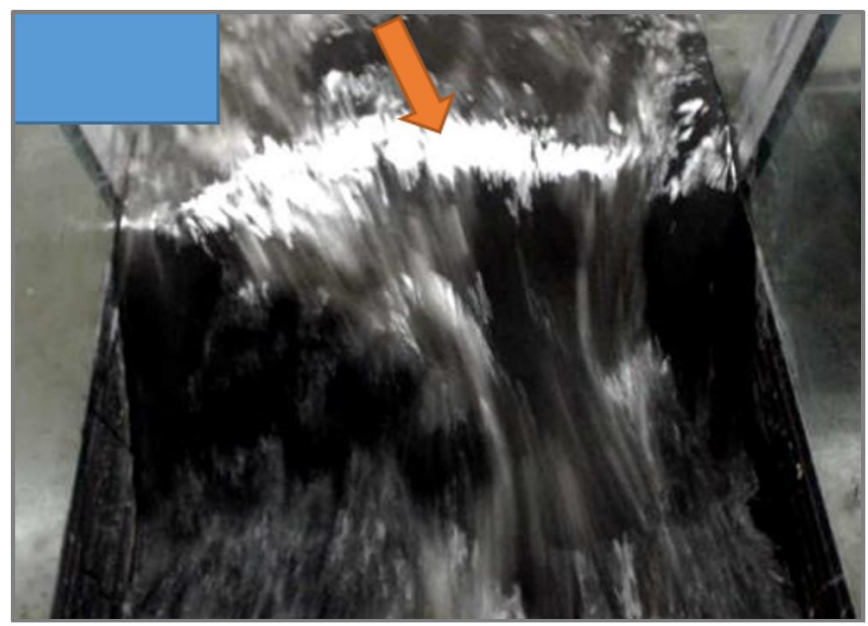

Figure 21. The concentration of flow in the central part of the dam indicates that the breach started rapidly at this location time 3':46".

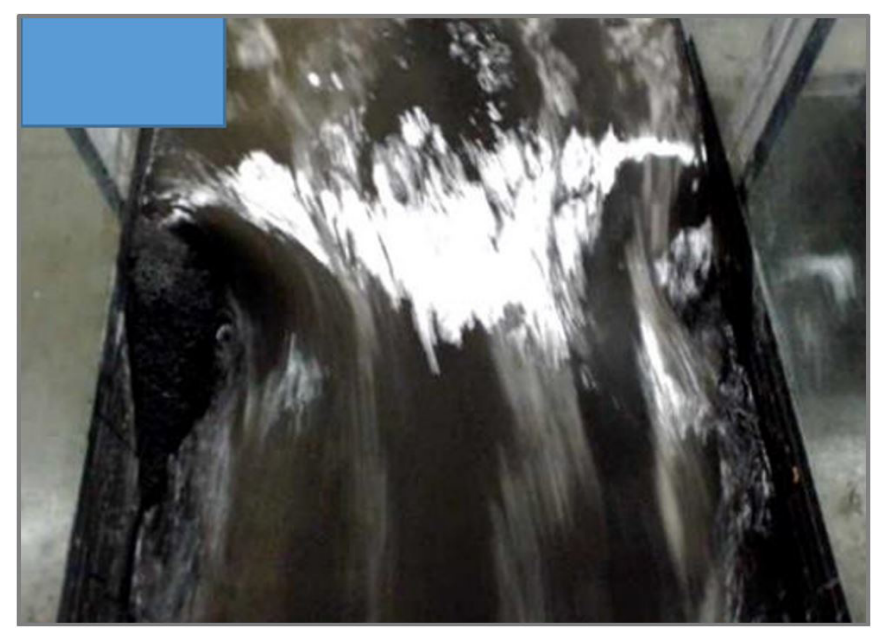

Figure 22. Downstream breach developed fast - time 3':49”.

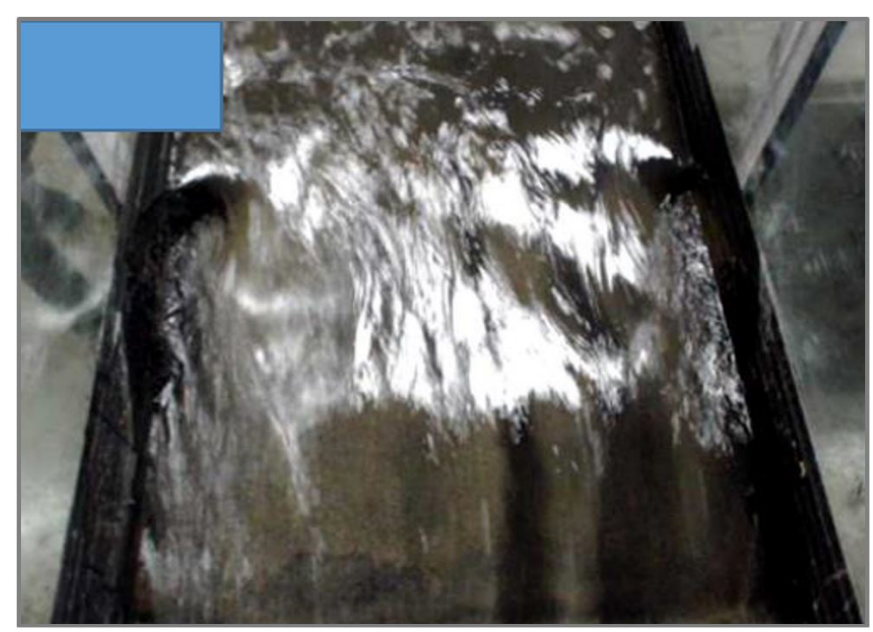

Figure 23. End of test on the downstream dam - time 4':06".

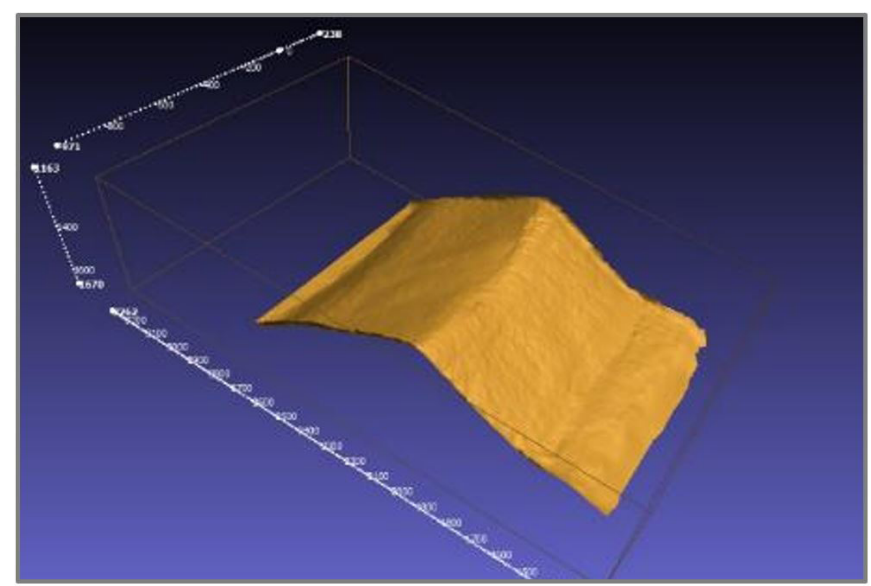

Figure 24. Scanned 3D view of upstream dam - Scenario I pre-rupture. 
Table 8. Scenario I (Tests 1, 2 and 3) and Scenario II (Tests 1, 2 and 3) results.

\begin{tabular}{|c|c|c|c|c|c|}
\hline Scenario & $\begin{array}{c}\text { BFF Upstream } \\
\left(\mathrm{m}^{3} . \mathrm{m}\right)\end{array}$ & $\begin{array}{c}\text { BFF Downstream } \\
\left(\mathrm{m}^{3} . \mathrm{m}\right)\end{array}$ & $\begin{array}{c}\text { BFF } \\
\text { correlation }\end{array}$ & $\begin{array}{c}\text { Width } \\
\text { correlation }\end{array}$ & $\begin{array}{c}\text { Time formation } \\
\text { correlation }\end{array}$ \\
\hline \multirow[t]{3}{*}{ I } & 0.504 & 0.067 & 0.133 & 1.34 & 0.33 \\
\hline & & & & 1.37 & 0.61 \\
\hline & & & & 1.26 & 0.77 \\
\hline Average & - & - & - & 1.32 & 0.57 \\
\hline \multirow[t]{3}{*}{ II } & 0.400 & 0.154 & 0.386 & 1.59 & 0.81 \\
\hline & & & & 1.30 & 0.86 \\
\hline & & & & 1.56 & 0.80 \\
\hline Average & - & - & - & 1.48 & 0.82 \\
\hline General average & - & - & - & 1.40 & 0.70 \\
\hline
\end{tabular}

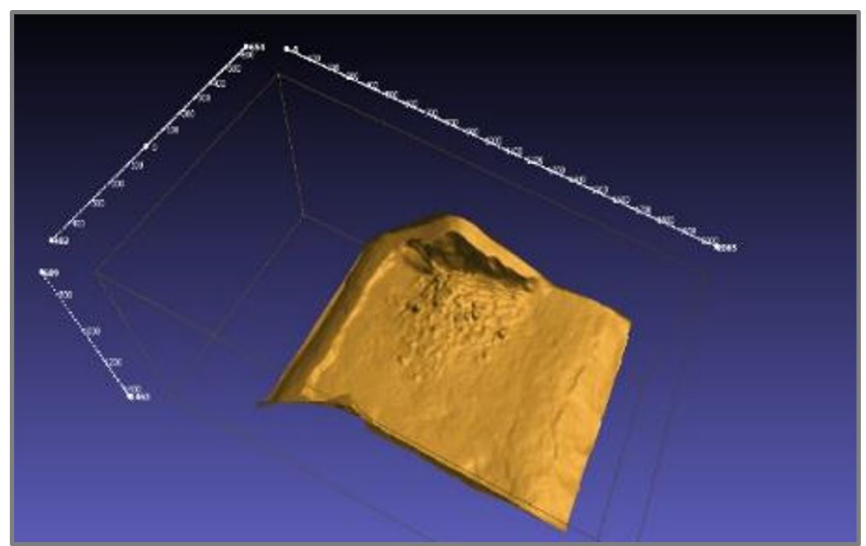

Figure 25. Scanned 3D view of upstream dam - Scenario I post-rupture.

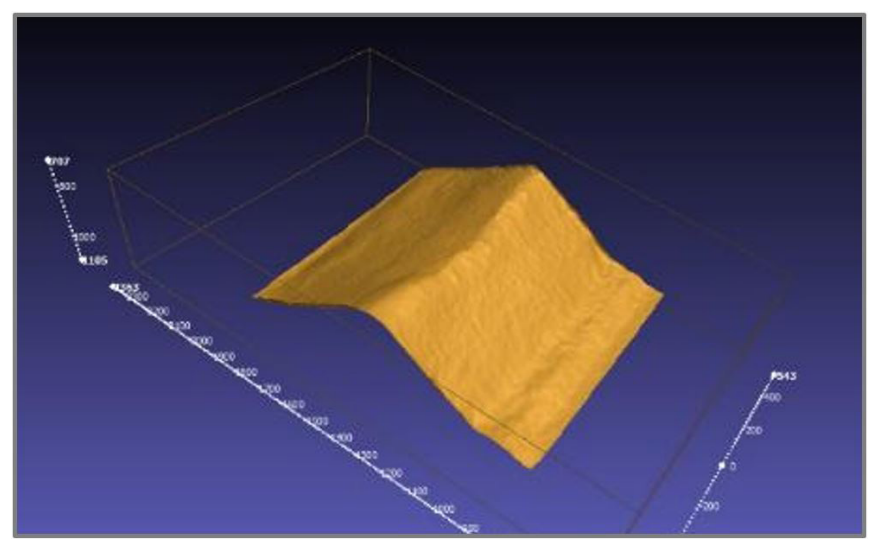

Figure 26. Scanned 3D view of downstream dam - Scenario I - pre-rupture.

\section{CONCLUSIONS}

RCWM material can be used to represent dams in rupture processes, especially in the overtopping failure mode, since this material is representative of the processes that occur in overtopping erosive rupture as verified by Campos et al. (2018a). Also, RCWM shows an advantage when compared to other materials as it is cheap, inert, non-erosive to channel structure, and pumping system, allowing greater reuse of the water and less impact on the

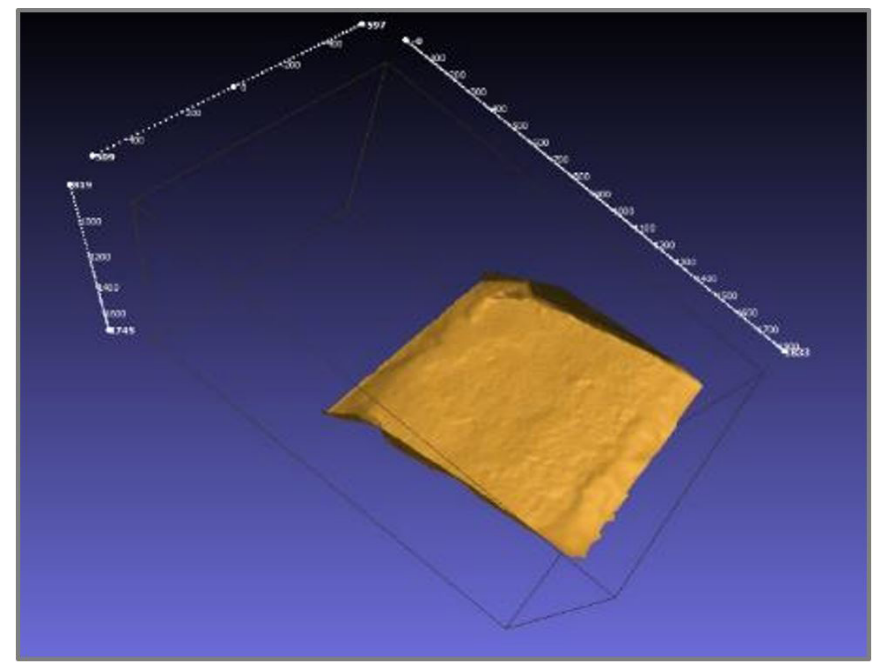

Figure 27. Scanned 3D view of downstream dam - Scenario I - post-rupture.

pumping system. However, its representativeness in each physical model still needs checking, and proper cement ratios determined.

The research had concluded that the downstream breach formation time is smaller than those usually found in the literature, in the case of a cascade dam break. Breach width and other geometric data also need adjustments in case of use on the downstream dams.

Results showed an increase of $40 \%$ in breach width and a reduction of $30 \%$ in breach formation time on cascade dam breaks (average values in Table 8). The adaptation of Froehlich's (2008) breach parameters equations on the downstream dam could be given by Equations 11 and 12:

$$
\bar{B}=1.40\left\{0.27 k_{o} V_{W}^{0.32} H^{0.04}\right\}
$$

$t_{f}=0.70\left\{63.2 \sqrt{\frac{V_{w}}{g H^{2}}}\right\}$

Thus, results indicate that the minimum breach time formation, exclusively for cascading dams, maybe $70 \%$ of the upstream dam time formation value (Table 8 ). With these equations, the ruptures 
hydrographs of any cascade dams' set can be adequately modeled to represent more accurately the extension of flood area, and, mainly, the shortest arrival time of the flood, allowing a more efficient emergency plan. However, these equations are initial and premature, requiring further testing to improve them.

An analysis of the lateral slopes' geometries $(\mathrm{h} / \mathrm{v})$ indicates that the values of the slope for the upstream dam breach are approximately 0.33 and for the downstream dam breach are around 0.16 , which means an increase of the slopes about $48 \%$ when comparing upstream and downstream dams.

This observation is quite limited, once the channel has only $1.0 \mathrm{~m}$ width. For the six tests, Scenarios I and II, just one out of the six simulated downstream dams (Scenario I Test 1) did not have its mass completely removed by the upstream dam break wave. This result implies that a larger breach width could be possible, and suggests the need for further testing in a broader model.

Also, future researches should explore physical models of cascading dams to evaluate the arrangements' variables between the dams, to verify their influence on the downstream breach formation process:

- Dam heights;

- Variation of the facing (clayey soil) of the upstream walls of the dams (piping);

- Rupture flow;

- Cement ratio in the RCWM.

Others points of interest to attend to the development of this research are:

- Further variation of the distance between dams, reservoir volumes, and surface areas to assess how these variables affect the dam breaches. Dam distance effects are currently under analysis and will be addressed in a future paper;

- Development of tests with physical models built with soil, using preferably clayey materials, to verify the validity of the found parameters in this research;

- Besides no backwater effect were observed in the tests done, evaluate the impacts of backwater into the breach development on the upstream dam;

- Development of studies with physical models to verify the occurrence of scale effects, and its implications on results. Although in the proceeded physical tests there are very close similitudes between model and prototype, were not used equipment able to measure variables, as velocities, pressure and water depth;

- Evaluation of the use of RCWM material for application by other rupture modes, mainly for piping failure mode.

\section{ACKNOWLEDGMENTS}

The authors acknowledge financial support from the Conselho Nacional de Desenvolvimento Científico e Tecnológico (CNPq), Fundação de Amparo à Pesquisa do Estado de Minas Gerais (FAPEMIG), and Serra do Facão Energia S.A. (SEFAC).

\section{REFERENCES}

Agência Nacional de Mineração - ANM (2019). Classificação das barragens de mineração brasileiras - Data base janeiro/2019 - Extração SIGBM para classificaşão. Brasil: DNPM. Retrieved in 2019, January 23, from http://www.anm.gov.br/assuntos/barragens/pasta-cadastronacional-de-barragens-de-mineracao/classificacao-oficial-anm

Altinakar, M. S., McGrath, M. Z., Dabak, T., Thomas, W., Scroggins, C., Gauntt, T., Harvey, H., \& Kelly, J. (2017). Two-dimensional dambreach flood modeling and inundation mapping with cascading failures. In Proceedings of the World Environmental and Water Resources Congress. Reston: ASCE. http://dx.doi.org/10.1061/9780784480625.034.

Bouchehed, H., Mihoubi, M. K., Derdous, O., \& Djemili, L. (2017). Evaluation of potential dam-break flood risks of the cascade dams Mexa and Bougous (El Taref, Algeria). Journal of Water and Land Development, 33(1), 39-45. http://dx.doi.org/10.1515/ jwld-2017-0017.

Briaud, J. L., Ting, F. C. K., Chen, H. C., Cao, Y., Han, S. W., \& Kwak, K. W. (2001). Erosion function apparatus for scour rate predictions. Journal of Geotechnical and Geoenvironmental Engineering, 127(2), 105-113. http://dx.doi.org/10.1061/(ASCE)10900241(2001)127:2(105).

Cai, W., Zhu, X., Peng, A., Wang, X., \& Fan, Z. (2019). Flood risk analysis for cascade dam systems: a case study in the dadu river basin in China. Water (Basel), 11(7), 1365. http://dx.doi. org/10.3390/w11071365.

Campos, R. G. D., Saliba, A. P. M., Baptista, M. B., Biscaro, V. H. B., Camargos, R. S., \& Passos, D. T. (2018b). Modelagem física para determinação de parâmetros de brechas em rupturas de barragens em cascata. In Anais do XXV III Congresso Latinoamericano de Hidráulica. Ezeiza, Argentina: Instituto del Agua.

Campos, R. G. D., Saliba, A. P. M., Camargos, R. S., Biscaro, V. H. B., \& Passos, D. T. (2018a). Determinação de taxas de erosão para mistura de borracha e cimento para aplicação em modelos reduzidos. In Anais do XXV III CONGRESSO Latino-americano de Hidráulica. Ezeiza, Argentina: Instituto del Agua.

Cao, Z., Huang, W., Pender, G., \& Liu, X. (2014). Even more destructive: cascade dam break floods. Flood Risk Management, 7(4), 357-373. http://dx.doi.org/10.1111/jfr3.12051.

Colorado Dam Safety Branch. (2010). Guidelines for dam breach analysis. Lexington: Association of State Dam Safety Officials.

Froehlich, D. C. (2008). Embankment dam breach parameters and their uncertainties. Journal of Hydraulic Engineering, 134(12), 1708-1720. http://dx.doi.org/10.1061/(ASCE)0733-9429(2008)134:12(1708).

Gonzalez-Jorge, H., Rodríguez-Gonzálvez, P., Martínez-Sánchez, J., González-Aguilera, D., Arias, P., Gesto, M., \& Díaz-Vilariño, L.. (2015). Metrological comparison between Kinect I and Kinect 
II sensors. Measurement., 70, 21-26. http://dx.doi.org/10.1016/j. measurement.2015.03.042.

Google Earth (2019). Google Earth Pro 7.3.2.5776 (64-bit). USA: Google Inc. Retrieved in 2019, March 13.

Huang, J., Li, J., \& Liang, P. (2018). Inflow flood simulation and risk analysis of cascade reservoirs. China: School of Renewable Energy North China Electric Power, University Beijing. http://dx.doi. org/10.1051/matecconf/201824601106.

Li, P., \& Liang, C. (2016). Risk analysis for cascade reservoirs collapse based on bayesian networks under the combined action of flood and landslide surge. Mathematical Problems in Engineering, 2016(2903935), 1-13. http://dx.doi.org/10.1155/2016/2903935.

Luo, J., Xu, W., Zhong, T., \& Chen, H. (2017). Numerical simulation of cascaded dam-break. flow in downstream reservoir. London: Institution of Civil Engineers.

MacDonald, T. C., \& Langridge-Monopolis, J. (1984). Breaching characteristics of dam failures. ASCE Hydraulic Engineering, 110(5), 567-586. http://dx.doi.org/10.1061/(ASCE)07339429(1984)110:5(567).

Saliba, A. P. M. (2009). Uma nova abordagem para análise de ruptura por galgamento de barragens homogêneas de solo compactado (Tese de doutorado). Universidade Federal de Minas Gerais, Belo Horizonte.

Shi, Z. M., Guan, S. G., Peng, M., Zhang, L. M., Zhu, Y., \& Cai, Q. P. (2015). Cascading breaching of the Tangijashan landslide dam and two smaller downstream landslide dams. Engineering Geology, 193, 445-458. http://dx.doi.org/10.1016/j.enggeo.2015.05.021.

U. S. Army Corps of Engineers - USACE. (2016). HEC-RAS river analysis system - bydraulic reference manual. Version 5.0.5 (pp. 47). USA: USACE. von Thun, J. L., \& Gillette, D. R. (1990). Guidance on breach parameters (Unpublished internal document, 17 p.). Denver: US Bureau of Reclamation.

Zhang, Y., \& Xu, W. (2017). Retarding effects of an intermediate intact dam on the dam-break flow in cascade reservoirs. Journal of Hydraulic Research, 55(3), 438-444. http://dx.doi.org/10.1080 /00221686.2016.1276103.

Zhou Z., Wang, X., Chen, W., Deng, S., \& Liu, M. (2017). Numerical simulation of dam-break flooding of cascade reservoirs. Heidelberg: SpringerVerlag GmbH. http://dx.doi.org/10.1007/s12209-017-0073-y.

\section{Authors contributions}

Rubens Gomes Dias Campos: Defined objectives and methodology, planned and conducted models tests, and wrote and formatted text.

Aloysio Portugal Maia Saliba: Defined objectives, made technical notes, and revised the text.

Márcio Benedito Baptista: Made technical notes and revised the text.

Victor Hugo Brum Biscaro: Participated on model tests.

Júlia Muniz de Miranda Sá: Participated on model tests.

Daniel Tuler Passos: Participated on model tests.

Stênio Augusto de Souza Coelho: Participated on model tests.

José Antonio Mamani Gómez: Participated on model tests. 